\title{
Sleep apnea syndrome caused lowering of cerebral oxygenation in a hemodialysis patient: a case report and literature review
}

Kiyonori Ito ${ }^{1}$, Susumu Ookawara ${ }^{1 *}$, Mariko Fueki ${ }^{2}$, Sojiro Imai ${ }^{2}$, Takashi Hattori ${ }^{2}$, Satoshi Kiryu ${ }^{2}$, Yukari Sugai ${ }^{3}$, Noriko Wada ${ }^{3}$, Mitsutoshi Shindo ${ }^{1}$, Yasushi Ohnishi ${ }^{4}$, Noriaki ino $^{5}$, Kaoru Tabei ${ }^{4}$ and Yoshiyuki Morishita ${ }^{1}$

\begin{abstract}
Background: Sleep apnea syndrome (SAS) is a sleep disturbance, which is frequently comorbid in dialysis patients. SAS induces hypoxia, and therefore, systemic and cerebral oxygenation would be low. Near-infrared spectroscopy (NIRS) has recently been used to measure regional saturation of oxygen $\left(\mathrm{rSO}_{2}\right)$, as a marker of tissue oxygenation. Although cerebral $\mathrm{rSO}_{2}$ was measured in patients in various clinical settings, few reports have previously shown the associations of changes in cerebral $\mathrm{rSO}_{2}$ and systemic oxygenation using measurement of peripheral arterial oxygen saturation $\left(\mathrm{SpO}_{2}\right)$ in patients undergoing hemodialysis (HD) with SAS. We herein report a first HD case with SASinduced reduction in cerebral oxygenation during sleep.

Case presentation: A 74-year-old woman underwent HD therapy for 1 month, because of advanced CKD caused by hypertension and obesity. In addition, she was diagnosed with obstructive sleep apnea with polysomnography about 4 years prior. Her apnea-hypopnea index (AHI) was 77.5 per hour, and therefore, continuous positive airway pressure (CPAP) was started. Thereafter, her AHI was improved to 3 to 6 per hour. However, she discontinued CPAP therapy at HD initiation. Since her oxygenation without CPAP would deteriorate, we evaluated her $\mathrm{SpO}_{2}$ and cerebral $\mathrm{rSO}_{2}$ by NIRS monitoring during sleep. We confirmed the deterioration in cerebral $\mathrm{rSO}_{2}$ according to the $\mathrm{SpO}_{2}$ decrease, and furthermore, the improvement in cerebral $\mathrm{rSO}_{2}$ was apparently delayed even after the improvement in her $\mathrm{SpO}_{2}$. The patient's cerebral oxygenation under CPAP therapy could not be evaluated because she refused to receive CPAP therapy after HD initiation. Therefore, as a comparison, we evaluated a 69-year-old male HD patient without SAS and found that in contrast to a patient with $\mathrm{SAS}$, his $\mathrm{SpO}_{2}$ and cerebral $\mathrm{rSO}_{2}$ were maintained throughout sleep.
\end{abstract}

Conclusion: We observed deterioration in cerebral oxygenation during sleep in addition to a decrease in systemic oxygenation in a patient with SAS undergoing HD. Real-time cerebral NIRS monitoring during sleep might be a useful method for detection of SAS.

Keywords: Cerebral oxygenation, Sleep apnea syndrome, Hemodialysis, Regional saturation of oxygen (rSO2), Near-infrared spectroscopy (NIRS)

\footnotetext{
* Correspondence: su-ooka@hb.tp1.jp

1Division of Nephrology, First Department of Integrated Medicine, Saitama

Medical Center, Jichi Medical University, 1-847 Amanuma-cho, Omiya-ku,

Saitama 330-8503, Japan

Full list of author information is available at the end of the article
}

(c) The Author(s). 2018 Open Access This article is distributed under the terms of the Creative Commons Attribution 4.0 International License (http://creativecommons.org/licenses/by/4.0/), which permits unrestricted use, distribution, and reproduction in any medium, provided you give appropriate credit to the original author(s) and the source, provide a link to the Creative Commons license, and indicate if changes were made. The Creative Commons Public Domain Dedication waiver (http://creativecommons.org/publicdomain/zero/1.0/) applies to the data made available in this article, unless otherwise stated. 


\section{Background}

Sleep apnea syndrome (SAS) is a sleep disturbance, which is frequently comorbid in dialysis patients $[1,2]$. SAS induces hypoxia during apnea, and therefore, systemic and cerebral oxygenation would be low in these patients. However, few reports have examined regarding the changes in cerebral oxygenation during sleep in patients with SAS. Near-infrared spectroscopy (NIRS) has recently been used to measure regional saturation of oxygen $\left(\mathrm{rSO}_{2}\right)$, as a marker of tissue oxygenation. In particular, cerebral $\mathrm{rSO}_{2}$ was measured in patients in various clinical settings, including hemodialysis (HD) patients [38]. It would be considered important to maintain cerebral $\mathrm{rSO}_{2}$ levels because that low cerebral $\mathrm{rSO}_{2}$ has been associated with cognitive impairment in patients with chronic kidney disease (CKD) [5, 8] and poor neurologic outcomes in post-cardiac arrest patients [7]. We aimed to examine the associations between changes in cerebral $\mathrm{rSO}_{2}$ and those in systemic oxygenation using the measurement of peripheral arterial oxygen saturation $\left(\mathrm{SpO}_{2} \%\right)$ in a patient undergoing HD with SAS.

\section{Case presentation}

A 74-year-old woman underwent HD therapy for 1 month, because of advanced CKD caused by hypertension and obesity. In addition, she was diagnosed with obstructive sleep apnea (OSA) with polysomnography about 4 years prior. Her apnea-hypopnea index (AHI) was 77.5 per hour and the arousal index was 76.1 per hour. Therefore, continuous positive airway pressure (CPAP) was started, and her AHI was improved to 3 to 6 per hour. However, she discontinued CPAP therapy at HD initiation. As systemic oxygenation would deteriorate without CPAP, we assessed her overnight $\mathrm{SpO}_{2}$ using a pulse oximeter (PULSOX-Me300; TEIJIN PHARMA, Tokyo, Japan). Additionally, for the evaluation of cerebral oxygenation, we monitored cerebral $\mathrm{rSO}_{2}$ using a regional saturation monitor (INVOS 5100c; Covidien Japan, Tokyo, Japan). Her vital sign and laboratory findings were as follows: blood pressure (BP) and pulse rate (PR) before evaluation; 127/71 $\mathrm{mmHg}, 76$ beats/minute, BP and PR after evaluation; 121/59 mmHg, 80 beats/minute, hemoglobin ( $\mathrm{Hb}): 9.5$ $\mathrm{g} / \mathrm{dL}$, serum albumin (Alb); $2.7 \mathrm{~g} / \mathrm{dL}$, blood urea nitrogen (BUN): $48.2 \mathrm{mg} / \mathrm{dL}$, serum creatinine $(\mathrm{Cr}): 4.13 \mathrm{mg} /$ dL. Her physiological function examination findings were as follows: ejection fraction (EF): 60\%, left ventricular systolic function was normal, mitral valve regurgitation was mild by echocardiography, and left and right carotid max intima-media thickness (IMT) were 1.1 and $1.1 \mathrm{~mm}$, respectively by carotid ultrasonography. Cerebral $\mathrm{rSO}_{2}$ level was evaluated as the $\mathrm{rSO}_{2}$ ratio, which was defined as the ratio of $\mathrm{rSO}_{2}$ at $t$ (min) during sleep to the initial $\mathrm{rSO}_{2}$ before bedtime $\left[\mathrm{rSO}_{2}\right.$ at $\mathrm{t}$ (min) during sleeping/initial $\mathrm{rSO}_{2}$ before bedtime]. We confirmed the deterioration in cerebral $\mathrm{rSO}_{2}$ according to the $\mathrm{SpO}_{2}$ decrease in this $\mathrm{HD}$ patient with SAS. However, we could not directly comment on the influence of CPAP therapy on the improvement in systemic oxygenation because she refused to receive CPAP therapy after HD initiation. Therefore, as a comparison, changes in $\mathrm{SpO}_{2}$ and cerebral $\mathrm{rSO}_{2}$ were evaluated in a 69-year-old male HD patient without SAS. His vital sign and laboratory findings were as follows: $\mathrm{BP}$ and $\mathrm{PR}$ before evaluation 135/92 $\mathrm{mmHg}, 68$ beats/minute, BP and PR after evaluation 148/100 mmHg, 61 beats/minute, $\mathrm{Hb} 11.1 \mathrm{~g} / \mathrm{dL}$, Alb $3.1 \mathrm{~g} / \mathrm{dL}$, BUN $55.7 \mathrm{mg} / \mathrm{dL}$, and Cr $7.86 \mathrm{mg} / \mathrm{dL}$. Results of his physiological function examination were as follows: EF: 71\%, left ventricular systolic function was normal contraction, no valvular disease was noted by echocardiography, and left and right carotid IMT was 3.2 and $2.4 \mathrm{~mm}$, respectively by carotid ultrasonography. Both patients provided informed consent before evaluation, and these examinations in each patient were performed on the day without $\mathrm{HD}$ therapy. The $\mathrm{SpO}_{2}$ gradually decreased in patients with SAS from initiation to $3 \mathrm{~h}$ after sleep and then fell below 90\%. According to the $\mathrm{SpO}_{2}$ decrease during sleep, her cerebral $\mathrm{rSO}_{2}$ simultaneously decreased; furthermore, the improvement in cerebral $\mathrm{rSO}_{2}$ was apparently delayed even after the improvement in her $\mathrm{SpO}_{2}$ (Fig. 1a). Her 3\% Oxygen Desaturation Index was 19.0 times/hour by pulse oximetry. However, as shown in Fig. 1b, both his $\mathrm{SpO}_{2}$ and cerebral $\mathrm{rSO}_{2}$ ratio were maintained throughout sleep in the HD patient without SAS.

\section{Discussion}

We experienced a HD patient with SAS who showed a decrease in cerebral oxygenation in addition to a decrease in systemic oxygenation during sleep. In general, a decrease in systemic oxygenation would induce the deterioration of tissue oxygenation, including the brain. However, thus far, few reports have directly examined changes in cerebral oxygenation during sleep. Therefore, this case is a first report about nocturnal real-time monitoring of cerebral $\mathrm{rSO}_{2}$ in a HD patient with SAS.

Sleep disorders, including SAS, are known as longterm complications in dialysis patients $[1,2]$. Nocturnal hypoxia was associated with a poor prognosis for cardiovascular events [9], and patients with ischemic stroke have a high risk of obstructive sleep apnea, with lowest overnight $\mathrm{SpO}_{2}$ values $<80 \%$ in more than half of observed patients [10]. Furthermore, in the clinical setting of HD therapy, cognitive impairment is common in patients undergoing $\mathrm{HD}$ and the pathogenesis of cognitive impairment would be associated with hemodynamic factors including changes in BP or anemia [11]. In particular, both intradialytic hypotension and anemia reportedly 

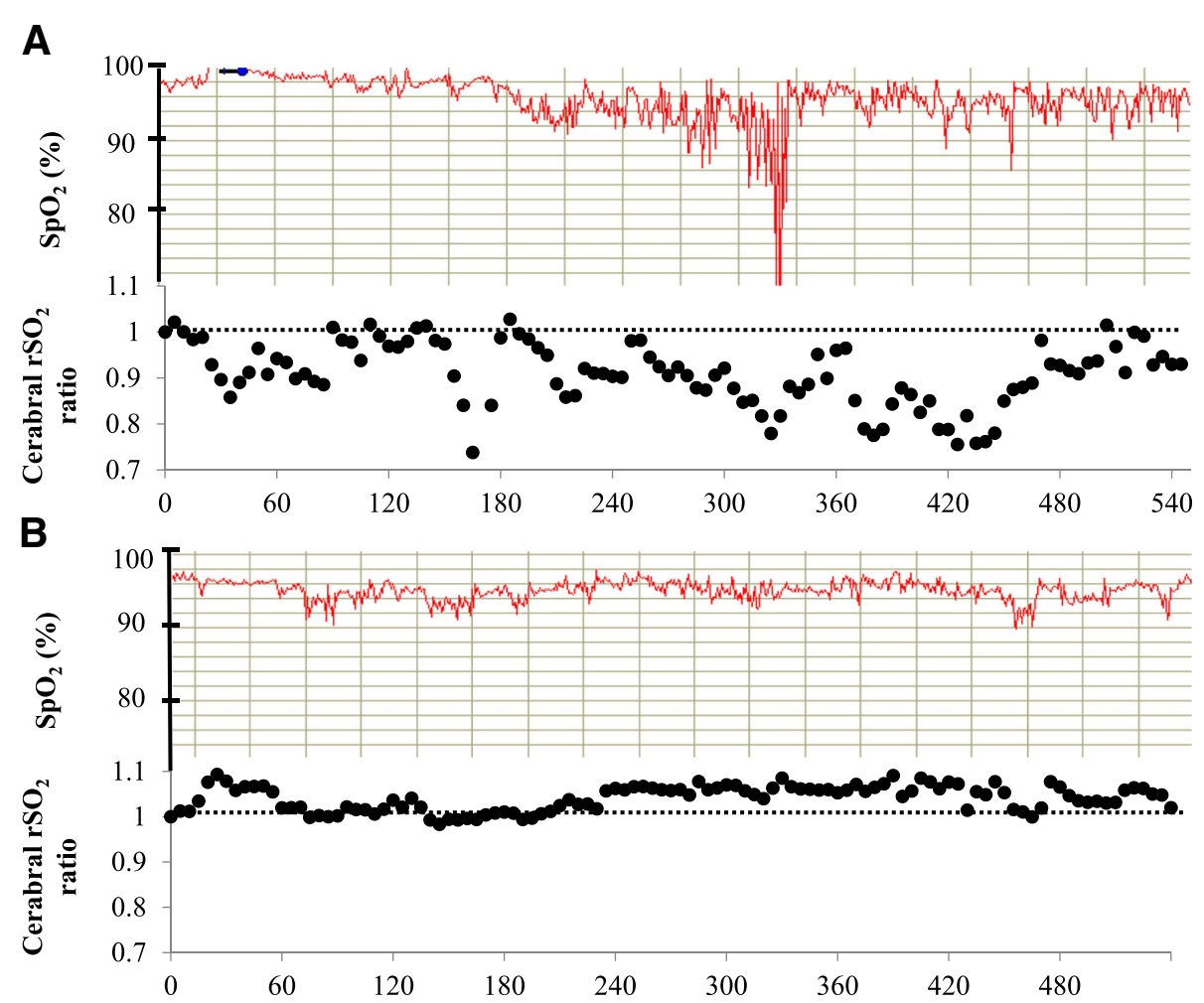

Fig. 1 Time course of $\mathrm{SpO}_{2}$ and cerebral $\mathrm{rSO}_{2}$ in a patient with obstructive $\mathrm{SAS}$ (a) and a patient without $\mathrm{SAS}$ (b). SpO 2 peripheral arterial oxygen saturation, $\mathrm{rSO}_{2}$ regional saturation of oxygen, and SAS sleep apnea syndrome

induced the deterioration of cerebral oxygenation [12, 13]. In addition, the decrease in cerebral oxygen supply was associated with neuronal death, and hypoxia promoted the formation of amyloid $ß$ peptide in experimental studies [14, 15]. Therefore, systemic oxygenation should be maintained to prevent worsening of cerebral oxygenation, which would be associated with the deterioration of cognitive function, in patients with SAS.

The measurement of cerebral $\mathrm{rSO}_{2}$ by NIRS has recently been performed in various clinical settings, including cardiovascular surgery, pediatrics, and dialysis $[3-8,16-18]$. We therefore, reviewed the literature for reports of cerebral $\mathrm{rSO}_{2}$ values in dialysis patients (Table 1). Cerebral $\mathrm{rSO}_{2}$ values in $\mathrm{HD}$ patients were lower than healthy control or non-dialysis patients $[3,8$, 19-21] and were lower than peritoneal dialysis patients [22]. Therefore, the presence of renal dysfunction or dialysis therapeutic modality might influence the status of cerebral oxygenation. Furthermore, longer HD therapy itself might cause hypoxia of the brain because HD duration was negatively associated with cerebral $\mathrm{rSO}_{2}[3,19]$. Regarding the association between cerebral $\mathrm{rSO}_{2}$ and clinical parameters in maintenance HD patients, various factors, i.e., serum albumin, $\mathrm{pH}, \mathrm{Hb}$, and blood pressure, were related to cerebral $\mathrm{rSO}_{2}[3,13,23]$. Based on these previous reports, it would be important to maintain the nutritional status, and control $\mathrm{Hb}$ level and blood pressure in the clinical setting of HD therapy. On the other hand, it was also reported that there are little changes in cerebral $\mathrm{rSO}_{2}$ during $\mathrm{HD}$ in spite of $\mathrm{Hb}$ increase induced by ultrafiltration in patients undergoing HD without intradialytic hypotension $[6,13,20,24]$. However, thus far, there are few reports regarding the association between changes in systemic oxygenation and those in cerebral oxygenation in HD patients with or without SAS. Recently, evaluation of cerebral $\mathrm{rSO}_{2}$ was reported to be useful for detection of SAS in addition to that using a pulse oximeter in children [18]. This report described that cerebral NIRS monitoring could detect SAS even in patients in whom SAS was ruled out with polysomnography, and AHI determined using cerebral $\mathrm{rSO}_{2}$ had higher sensitivity for the detection of SAS compared with that using $\mathrm{SpO}_{2}$ [18]. In HD patients with SAS, we noticed that a decrease in cerebral $\mathrm{rSO}_{2}$ was observed more frequently than a decrease in $\mathrm{SpO}_{2}$, and this result might be consistent with a previous report [18]. On the other hand, the HD patient without SAS in this study showed little changes in $\mathrm{SpO}_{2}$ and cerebral $\mathrm{rSO}_{2}$ during sleep. Therefore, in addition to the usefulness of polysomnography evaluation as a standard method for diagnosing SAS, cerebral $\mathrm{rSO}_{2}$ measurement using NIRS might play an important role in the diagnosis of SAS in HD patients. 
Table 1 Studies regarding cerebral oxygenation by near-infrared spectroscopy monitoring in dialysis patients

\begin{tabular}{|c|c|c|c|c|c|}
\hline Authors & Year & $\begin{array}{l}\text { Dialysis } \\
\text { pattern }\end{array}$ & $\begin{array}{l}\text { Number of } \\
\text { patients }\end{array}$ & Main results about cerebral oxygenation & Reference \\
\hline Prohovnik I, et al. & 2007 & $\mathrm{HD}$ & 7 & $\begin{array}{l}\text { Cerebral } \mathrm{rSO}_{2} \text { in } \mathrm{HD} \text { patients was lower than healthy control, and } \\
\text { cerebral } \mathrm{rSO}_{2} \text { was negatively correlated with dialysis duration. }\end{array}$ & [19] \\
\hline Papadopoulos G, et al. & 2013 & $\mathrm{HD \& PD}$ & $23(\mathrm{HD}), 9$ (PD) & $\begin{array}{l}\text { Cerebral } \mathrm{rSO}_{2} \text { in } \mathrm{HD} \text { patients was lower than that in } \mathrm{PD} \text { patients } \\
\text { at preoperative condition. }\end{array}$ & [22] \\
\hline Hoshino T, et al. & 2014 & $\mathrm{HD}$ & 18 & $\begin{array}{l}\text { Cerebral } \mathrm{rSO}_{2} \text { in } \mathrm{HD} \text { patients was lower than healthy control, and } \\
\text { cerebral } \mathrm{rSO}_{2} \text { did not change during } \mathrm{HD} \text {. }\end{array}$ & {$[20]$} \\
\hline Ito K, et al. & 2015 & $\mathrm{HD}$ & 54 & $\begin{array}{l}\text { Cerebral } \mathrm{rSO}_{2} \text { in } \mathrm{HD} \text { patients was lower than healthy control, and } \\
\text { cerebral } \mathrm{rSO}_{2} \text { was independently correlated with } \mathrm{pH} \text {, dialysis duration, } \\
\text { serum albumin, and diabetes mellitus. }\end{array}$ & {$[3]$} \\
\hline Ito K, et al. & 2017 & $\mathrm{HD}$ & 16 & $\begin{array}{l}\text { Cerebral } \mathrm{rSO}_{2} \text { in } \mathrm{HD} \text { patients with severe anemia was lower than that } \\
\text { in } \mathrm{Hb} \text { well-controlled } \mathrm{HD} \text { patients, and blood transfusion improved } \\
\text { cerebral } \mathrm{rSO}_{2} \text {. }\end{array}$ & [13] \\
\hline MacEwen C, et al. & 2017 & $\mathrm{HD}$ & 58 & $\begin{array}{l}\text { Cerebral } \mathrm{rSO}_{2} \text { was linearly dependent blood pressure below mean } \\
\text { arterial pressure } 60 \mathrm{mmHg} \text {. }\end{array}$ & [23] \\
\hline Malik J, et al. & 2017 & $\mathrm{HD}$ & 17 & $\begin{array}{l}\text { Cerebral } \mathrm{rSO}_{2} \text { was drop in the minimum value during the first } 35 \mathrm{~min} \text {, } \\
\text { but cerebral } \mathrm{rSO}_{2} \text { did not change between before } \mathrm{HD} \text { and after } \mathrm{HD} \text {. }\end{array}$ & [24] \\
\hline Ito K, et al. & 2017 & $\mathrm{HD}$ & 108 & Cerebral $\mathrm{rSO}_{2}$ was correlated with aortic arch calcification by chest X-ray. & [4] \\
\hline Matsukawa S, et al. & 2017 & $\mathrm{HD}$ & 9 & $\begin{array}{l}\text { Cerebral } \mathrm{rSO}_{2} \text { in } \mathrm{HD} \text { patients was lower than that in non-HD patients, } \\
\text { although } \mathrm{SpO}_{2} \text { did not differ between } \mathrm{HD} \text { and non-HD patients. }\end{array}$ & [21] \\
\hline Kovarova L, et al. & 2018 & $\mathrm{HD}$ & 39 & Decreased cerebral $\mathrm{rSO}_{2}$ was associated with cognitive impaired. & [5] \\
\hline Ookawara S, et al. & 2018 & $\mathrm{HD}$ & 44 & $\begin{array}{l}\text { Cerebral } \mathrm{rSO}_{2} \text { did not change during } \mathrm{HD} \text {, and it was lower than liver } \\
\mathrm{rSO}_{2} \text { from } \mathrm{HD} \text { initiation to the end. }\end{array}$ & [6] \\
\hline
\end{tabular}

$H D$ hemodialysis, $P D$ peritoneal dialysis, $r \mathrm{SO}_{2}$ regional saturation of oxygen

Furthermore, the improvement in cerebral $\mathrm{rSO}_{2}$ was apparently delayed even after the improvement in $\mathrm{SpO}_{2}$ level (Fig. 1a). Although it is difficult to accurately state the mechanism of this phenomenon, we suspected two reasons regarding the difference between systemic and cerebral oxygenation improvement. First, NIRS monitoring was reported to have higher sensitivity for detecting SAS [18]. Therefore, the delay in cerebral oxygenation improvement might have the possibility to reflect the deep tissue oxygenation status, which was different from superficial arterial oxygenation status as shown in $\mathrm{SpO}_{2}$ monitoring. Second, NIRS monitoring would mainly help observe venous oxygenation status (70-80\%), against capillary (5\%), or arterial blood (20-25\%) [25]. On the other hand, $\mathrm{SpO}_{2}$ monitoring could observe in the arterial blood oxygenation status. Brain cell would need the uptake of steady amount of oxygen into the cell according to the changes in oxygen supply in various conditions. In situations of decreased oxygen supply to brain such as severe anemia or hypoxic condition in SAS, cerebral $\mathrm{rSO}_{2}$ would be low, which reflected the decrease of oxygen supply and the increase of oxygen extraction into the brain cell [13]. When hypoxic status in SAS transiently disappears during sleep, arterial oxygenation will be immediately improved, which lead to the $\mathrm{SpO}_{2}$ increase. However, changes in oxygen extraction into brain cell might not be immediately normalized in response to the sudden increase of oxygen supply. As a result, there will be a lag time between the improvement in cerebral oxygenation and that of systemic oxygenation during sleep in this SAS patient. However, the mechanism of this phenomenon is yet not to be accurately clarified, and therefore, further studies are needed.

The use of CPAP improves systemic hypoxia in patients with SAS, and patients with OSA may have better outcomes under CPAP therapy through a decrease in the rate of recurrent myocardial infarction [26]. According to her prior medical records, the patient's AHI became relatively low under CPAP therapy compared to that without CPAP. Therefore, CPAP therapy would be effective in the prevention of systemic hypoxia during non-HD periods. Based on this result, cerebral oxygenation could be improved by CPAP therapy in patients with SAS in addition to the improvement of systemic oxygenation. However, further studies are needed to confirm the association between improvement in cerebral oxygenation and CPAP therapy in patients with SAS because we were unable to observe these associations in this study.

In conclusion, we observed cerebral oxygenation deterioration during sleep in addition to a decrease in systemic oxygenation in a patient undergoing HD with SAS. Furthermore, cerebral NIRS monitoring during sleep might be a useful method for the detection of SAS. 


\section{Acknowledgements}

We thank the study participants and the clinical dialysis center staff in Minami-Uonuma City Hospital.

\section{Funding}

The authors declare that there is no funding related to this manuscript.

\section{Availability of data and materials}

All data analyzed during this study are included in this published article.

\section{Authors' contributions}

$\mathrm{KI}$ conceived and designed this study. KI, MF, SI, TH, SK, YS, NW, and MS performed this study. $\mathrm{KI}$ and $\mathrm{OS}$ analyzed the data. $\mathrm{YO}, \mathrm{NI}, \mathrm{KT}$, and $\mathrm{YM}$ supervised the data collection and manuscript preparation. KI and OS drafted the manuscript. All authors read and approved the final manuscript.

\section{Ethics approval and consent to participate}

Written informed consent was obtained from the patient after a detailed explanation of the objectives of the study, which was approved by the Institutional Review Board of Minami-Uonuma City hospital, Japan (H29-3). The patient anonymity should be preserved.

\section{Consent for publication}

For publication of this case report, agreement was obtained from the patient.

\section{Competing interests}

The authors declared that they have no competing interests.

\section{Publisher's Note}

Springer Nature remains neutral with regard to jurisdictional claims in published maps and institutional affiliations.

\section{Author details}

${ }^{1}$ Division of Nephrology, First Department of Integrated Medicine, Saitama Medical Center, Jichi Medical University, 1-847 Amanuma-cho, Omiya-ku, Saitama 330-8503, Japan. ${ }^{2}$ Department of Clinical Engineering, Minami-Uonuma City Hospital, Niigata, Japan. ${ }^{3}$ Department of Nursing, Minami-Uonuma City Hospital, Niigata, Japan. ${ }^{4}$ Department of Internal Medicine, Minami-Uonuma City Hospital, Niigata, Japan. ${ }^{5}$ Department of Nephrology, Uonuma Institute of Community Medicine, Niigata University Medical and Dental Hospital, Minami-Uonuma, Niigata, Japan.

Received: 20 September 2018 Accepted: 27 November 2018 Published online: 13 December 2018

\section{References}

1. Parker KP. Sleep disturbances in dialysis patients. Sleep Med Rev. 2003;7: 131-43.

2. Forni Ogna V, Ogna A, Pruijm M, Bassi I, Zuercher E, Halabi G, et al. Prevalence and diagnostic approach to sleep apnea in hemodialysis patients: a population study. Biomed Res Int. 2015;2015:103686.

3. Ito K, Ookawara S, Ueda Y, Goto S, Miyazawa H, Yamada H, et al. Factors affecting cerebral oxygenation in hemodialysis patients: cerebral oxygenation associates with $\mathrm{pH}$, hemodialysis duration, serum albumin concentration, and diabetes mellitus. PLoS One. 2015;10:e0117474.

4. Ito K, Ookawara S, Okochi T, Ueda Y, Kofuji M, Hayasaka H, et al. Deterioration of cerebral oxygenation by aortic arch calcification progression in patients undergoing hemodialysis: a cross-sectional study. Biomed Res Int. 2017:2017:2852514.

5. Kovarova L, Valerianova A, Kmentova T, Lachmanova J, Hladinova Z, Malik J. Low cerebral oxygenation is associated with cognitive impairment in chronic hemodialysis patients. Nephron. 2018;139:113-9.

6. Ookawara S, Ito K, Ueda Y, Miyazawa H, Hayasaka H, Kofuji M, et al. Differences in tissue oxygenation and changes in total hemoglobin signal strength in the brain, liver, and lower-limb muscle during hemodialysis. J Artif Organs. 2018;21:86-93.

7. Nishiyama K, Ito N, Orita T, Hayashida K, Arimoto H, Beppu S, et al. Regional cerebral oxygen saturation monitoring for predicting interventional outcomes in patients following out-of-hospital cardiac arrest of presumed cardiac cause: a prospective, observational, multicenter study. Resuscitation. 2015;96:135-41.
8. Miyazawa H, Ookawara S, Ito K, Ueda Y, Yanai K, Ishii H, et al. Association of cerebral oxygenation with estimated glomerular filtration rate and cognitive function in chronic kidney disease patients without dialysis therapy. PLoS One. 2018;13:e0199366.

9. Zoccali C, Mallamaci F, Tripepi G. Nocturnal hypoxemia predicts incident cardiovascular complications in dialysis patients. J Am Soc Nephrol. 2002;13:729-33.

10. Good DC, Henkle JQ, Gelber D, Welsh J, Verhulst S. Sleep-disordered breathing and poor functional outcome after stroke. Stroke. 1996;27:252-9.

11. Moeini M, Lu X, Avti PK, Damseh R, Belanger S, Picard F, et al. Compromised microvascular oxygen delivery increases brain tissue vulnerability with age. Sci Rep. 2018;8:8219.

12. Miyazawa H, Ookawara S, Tabei K. Aggravation of cerebral oxygenation due to intradialytic hypotension induced by blood volume reduction during hemodialysis: a case report. Ther Apher Dial. 2015;19:525-7.

13. Ito K, Ookawara S, Ueda Y, Miyazawa H, Kofuji M, Hayasaka H, et al. Changes in cerebral oxygenation associated with intradialytic blood transfusion in patients with severe anemia undergoing hemodialysis. Nephron Extra. 2017:7:42-51.

14. Peers C, Dallas ML, Boycott HE, Scragg JL, Pearson HA, Boyle JP. Hypoxia and neurodegeneration. Ann N Y Acad Sci. 2009;1177:169-77.

15. Peers C, Pearson HA, Boyle JP. Hypoxia and Alzheimer's disease. Essays Biochem. 2007:43:153-64.

16. Kobayashi K, Kitamura T, Kohira S, Torii S, Horai T, Hirata M, et al. Factors associated with a low initial cerebral oxygen saturation value in patients undergoing cardiac surgery. J Artif Organs. 2017;20:110-6.

17. Baik N, Urlesberger B, Schwaberger B, Avian A, Mileder L, Schmölzer GM, et al. Blood pressure during the immediate neonatal transition: is the mean arterial blood pressure relevant for the cerebral regional oxygenation? Neonatology. 2017;112:97-102.

18. Ullman N, Anas NG, Izaguirre E, Haugen W, Ortiz H, Arguello O, et al. Usefulness of cerebral NIRS in detecting the effects of pediatric sleep apnea. Pediatr Pulmonol. 2014;49:1036-42.

19. Prohovnik I, Post J, Uribarri J, Lee H, Sandu O, Langhoff E. Cerebrovascular effects of hemodialysis in chronic kidney disease. J Cereb Blood Flow Metab. 2007;27:1861-9.

20. Hoshino T, Ookawara S, Goto S, Miyazawa H, Ito K, Ueda Y, et al. Evaluation of cerebral oxygenation in patients undergoing long-term haemodialysis. Nephron Clin Pract. 2014;126:57-61.

21. Matsukawa S, Hamada M, Mizota T. Low preoperative regional cerebral oxygen saturation in hemodialysis patients. JA Clin Rep. 2017;3:13.

22. Papadopoulos G, Dounousi E, Papathanasiou A, Papathanakos G, Tzimas P. Cerebral oximetry values in dialyzed surgical patients: a comparison between hemodialysis and peritoneal dialysis. Ren Fail. 2013;35:855-9.

23. MacEwen C, Sutherland S, Daly J, Pugh C, Tarassenko L. Relationship between hypotension and cerebral ischemia during hemodialysis. J Am Soc Nephrol. 2017;28:2511-20.

24. Malik J, Kudlicka J, Lachmanova J, Valerianova A, Rocinova K, Bartkova M, et al. Tissue ischemia worsens during hemodialysis in end-stage renal disease patients. J Vasc Access. 2017:18:47-51.

25. Lemmers PMA, Toet MC, van Bel F. Impact of patent ductus arteriosus and subsequent therapy with indomethacin on cerebral oxygenation in preterm infants. Pediatrics. 2008;121:142-7.

26. Garcia-Rio F, Alonso-Fernández A, Armada E, Mediano O, Lores V, Rojo B, et al. CPAP effect on recurrent episodes in patients with sleep apnea and myocardial infarction. Int J Cardiol. 2013;168:1328-35.

\section{Ready to submit your research? Choose BMC and benefit from:}

- fast, convenient online submission

- thorough peer review by experienced researchers in your field

- rapid publication on acceptance

- support for research data, including large and complex data types

- gold Open Access which fosters wider collaboration and increased citations

- maximum visibility for your research: over $100 \mathrm{M}$ website views per year

At BMC, research is always in progress.

Learn more biomedcentral.com/submission 